\title{
Post-Clear and Clean License Social Practices of Mining In Indonesia: A Case Study of Conflict Resolution of A Company obtaining Clear and Clean License
}

\author{
Alen Saprika ${ }^{1}$, Afrizal $^{2}$, Azwar $^{3}$ \\ \{alensaprika@gmail.com ${ }^{1}$ \} \\ Department of Sociology, Andalas University, Padang, Indonesia
}

\begin{abstract}
The concept of clear and clean permit has been implemented since 2011 by the Indonesia government to produce sustainable mining practices. The government applies this concept due to the occurrence of many mining conflicts in Indonesia. This article presents the results of research concerning the influence of clear and clean permits to social practices of mining. The study used the structuration theory. Based on this theory what has been studied is that use of regulations by mining companies, related government agencies, and local communities to legitimize and understands their actions and mining reality. For this, a case PT. Tripabara operating in Nagari Lunang Utara has been studied using a qualitative research method. This article would like to show that although the company has obtained a clear and clean license, sustainable mining practices are not carried out. It will be discussed in this article the causes of unsustainable mining practices by PT. Tripabara. Two things will be revealed: the first is status of clear and clean permits obtained by the company is used by the company officials to claim that their mining practice is sustainable, while the community based their understanding of the company behavior on the company's actions to tackle environmental problems and conflict of land acquisition.
\end{abstract}

Keywords: Mining, Mining Company, Sustainable Mining, Mining Conflict, Clear and Clean License.

\section{Introduction}

The conflict over natural resources is not a new issue in Indonesia. Many phenomena are presenting three social groups with different interests: the local society, the business holder, and the state. Those three stakeholders compete over the available natural resources such as land, minerals, water source, and water itself. This issue shows that the local society has the urge to fight against the state and the business holder for their rights on their lands and resources [1].

Many conflicts over natural resources take place in Indonesia including the plantations, lands, forests, and minerals. The conflict rarely discussed in social studies, i.e. Sociology is the conflict over mining activities with an overlapping ownership claim between the business holder and the society. Moreover, there is an unclear actor to whom the responsibility towards the mining waste management must be relied upon [2].

The mining activities was once aimed at improving as well as advancing the society's economy. However, it turns out that those mining activities result in some social conflicts. There 
have been many conflicts over mining activities occur such as the conflict on environmental pollution, land ownership rights, labor conflict, project/work territorial contracts, overlapping claims on mining activities permission, community development program, and the conflict between the local dwellers and the mining company.

The Huma community has recorded that at least there have been 51 conflicts between the mining company and the local society [3]. As for the mining conflicts in West Sumatera, Qbar Community recorded that 23 conflicts have occurred between 2011-2015 [4].

Mining is defined as the whole activities involved for research, maintenance, and entrepreneurship, or if it is a coal mining the activities involved will be a general investigation, exploration, the study of feasibility, construction, mining, processing and purification, transporting and selling, and post-mining activities. Mining is categorized into two groups: mineral mining [4] and coal mining [5].

Coals become the main mining commodity for improving Indonesian economy. Based on the data from Geological bodies of 2013, Indonesian total coal stock increased from 120.525,4 million ton in 2011 to $31.357,1$ million ton in 2013. The number of coal resource towards the national production in Indonesia is still equally spread. The Borneo Island, for instance, possesses $58 \%$ of total national production contributes up to $92 \%$ of Indonesian annual coal production, while Sumatera Island whose predicted coal is $48 \%$ contributes $8 \%$ to Indonesian annual coal production.

The main issue of mining lies in its permission either from the government or from the local community. Therefore, it is expected that fixing the permission mechanism will result in the mining conflict resolution. To reach this goal, the Indonesian government employs 'clean and clear' concept. The clean and clear concept is described as a certificate released by the General Director of Mineral and Coal for the Business Permission Holder who has fulfilled the administrative, the geographical, technical, environmental, and financial requirements. Finally, it is considered as clear environmentally and financially stable [6]

The General Director of Minerals and Coals have recorded that there have been 10.640 Business Permission Holder between 2014 and October 7th, 2016, there were 5.976 or as $56,13 \%$ clear and clean Business Permission Holders, while for the unclear and unclean one was recorded as 4.672 or $43,87 \%$ [7]. The clean and clear permission were not included into the category of overlapping in the same commodity, different commodity, across interest, the additional document has been completed, and the coordinate is appropriate with the Letter of Reference [8]. In West Sumatera, up until 2016, there have been 281 Business Permission Holders released by the Ministry of Natural Resources consisting of 136 with clean and clear permission as well as 145 unclear and clean one [9]. It can be safely interpreted that the mining industry in West Sumatera is not well-managed.

PT. Tripabara is a company currently operating in West Sumatera, which has already been attained the legal permission to run in Ulayat Panghulu Nan Salapan in Lunang Utara Subdistrict, Lunang District. PT. Tripabara has been legalized with a clean and clear a letter of Business Permission Holder. Consequently, it is free from any legal issues. However, since this company runs there, there have been a couple of problems appear in that region such as its land acquisition and its production.

Additionally, in social perspective, there are arguments between Penghulu Nan Salapan and his cousin as well as his children on the income of the mining activities. Environmentally, while there is no environmental problems occurred in Lunang Utara Sub-district, Lunang District before mining activities there, nowadays it has caused a flood in the rainy season, and the catchment area is now more prone to drought in the dry season. Another impact is on the society's economy. Due to the frequent mining activities, water flow is damaged causing the 
water unable to water the society's paddy fields. As a result, there is a significant decline or even the failure on the harvest. Even though PT. Tripabara has held the Mining Legal Permission, but there are still problems arise during the mining activities take place which leads to the conflict between the company and the local society.

Based on the problem identifications above, this research is intended to reveal the causes to the inefficacy of the Letter of Business Permission towards the problem resolution between the company and the society of Lunang Utara Sub-district. The advantage of this research is to provide knowledge and understanding towards the agrarian conflicts.

\section{Methods}

This research was conducted in 8 months, from April to November 2016 in Lunang Utara Sub-district, Lunang District, Pesisir Selatan Regency, West Sumatera Province. The data in this research are grouped into primary and secondary data. The primary data were collected through the interview process, while the secondary ones were collected from the other related stakeholders. The theory of structural organization was employed in this research. According to the theory of structural organization, several important points should be taken into consideration such as the rules implemented by the mining industries, governmental bodies which have the authority in governing those mining industries, and the local society who legitimize their activities. More importantly, this research deployed qualitative research.

\section{Results and Discussions}

Based on the research conducted in 8 months, there were several points to explain and elaborate such as follow:

Both parties, PT. Tripabara and the society of Lunang Utara Sub-district did not obey the rules they have created before mining activities running. This matter leads to the arguments between mamak (a respected man in Minangkabau as a local culture) and kemenakan (descendants of mamak's sister) as well as his children. The problem had occurred before the company obtained the Business Permission Holder. It is proven that the problems can not be solved by a company with its Business Permission Holder, which can be explained using several theories below:

\subsection{The shared profits were not given}

Ever since the Memorandum of Understanding (MoU) between PT. Tripabara and Penghulu Nan Salapan upon the cession of the heritage land were signed on August 2, 2007; the two parties have to obey the regulations written in the document. One of the articles was that the second party (PT. Tripabara) is responsible for paying the shared profits to the first party (Penghulu Nan Salapan) at the time the mining starts as much as $10.000 \mathrm{Mt}$ and when the company produces more than $10.000 \mathrm{Mt}$.

The company has exploited the mining location, but it does not pay the shared profits to Penghulu Nan Salapan (the first party) in accordance with the MoU. However, there was a rumor that the company has paid the shared profits to Penghulu Nan Salapan. The rumor eventually causes the arguments between mamak and his kemenakan and children. 


\subsection{The session of the heritage land was not acknowledged by all parties should be involved}

PT. Tripabara has been registered as Incorporated Company Kantor Pelayanan Perizinan Terpadu dan Penanaman Modal Kabupaten Pesisir Selatan with register number 030514600039 on behalf of Ir. Rahmayudin. Based on the constitution of Republic of Indonesia article number 3 of 1982 on the Mandatory Industry Registration and the article number 40 of 2007 on Incorporated Company, thus PT. Tripabara has been legal. As a registered company, PT. Tripabara has the right to hold the Business Permission Holder in accordance to the constitution article number 4 of 2009 on Mineral Mining and Coal Mining which permits the company, corporate, or the local community to gain profit from coal and mineral mining based on the region's autonomy. Besides, the mining industry must also be operated within the environmental principle, check and balance, and society's participation.

As Lunang Utara Sub-district has been decided as the mining location the local government of Pesisir Selatan, the chief director of PT. Tripabara creates a MoU on the acquisition of 2,000 hectares inherited land with Penghulu Nan Salapan. Traditionally, Penghulu Nan Salapan has the authority to manage the land acquisition since they are the leader whose authority is maintaining the social welfare of their cousins and children. Nevertheless, before a decision making, there must be a discussion involving the society, other stakeholders in the region, children, and cousins. An important point to consider is that the inherited land belongs to Nagari (Lunang Utara Sub-district); it does not belong to an ethnic nor a group of society. Therefore, the inherited land has not been cultivated by the children and cousins. Hence it may be cultivated by another stakeholder apart from Penghulu Nan Salapan's children and cousins.

The tradition of inheriting the land to be managed either by the children and cousins or the whole society in a Nagari (sub-district) has impeded the process of obtaining clean and clear permission because of lack of transparency and participation of the whole stakeholders responsible in it. Consequently, the clean and clear permission cannot overcome the conflict between the company and the local society. Giddens sees that individuals have an important role in resolving a conflict since they possess the knowledge, the freedom to think, to take initiatives, and to actualize themselves based on their understanding to reach a goal, make a decision, and consider the impacts of the decision they have made. What is problematic in this regard is the quality of human resources in Lunang Utara is still low that they do not contribute much in realizing their goals.

Referring to the result of a research conducted by Wahana Lingkungan Hidup (Walhi) of West Sumatera, it is revealed that there is a low society's participation in the process of creating a MoU on inherited land acquisition. Moreover, societal rejection towards the investor has never been taken into serious consideration by the local government in issuing the Business Permission Holder of Exploration and Business Permission Holder of Operation Production.

\subsection{No solution towards the environmental damage}

The legal permission acquired by PT. Tripabara includes both the Responsibility on Environmental Protection and the Responsibility on Environmental Monitoring of 199 hectare land. Using this permission, PT. Tripabara has also gained access to open the mining locationclearing the land before starting the mining activities. The land clearing was executed on a concession land of 199 hectares in the Area of Restricted Forestry Production. A massive logging, as well as a barren land in the concession area, have vanished the green area and leave it with a yellow color and a barren land. The barren land was used to be Batang Kumbung river's upstream which pumps off the water towards the society's paddy fields in Lunang Utara. Due to a land clearing there, there is a dramatic decline in the water supply, thus it is unable to 
drainage the paddy fields maximally as it is used to be. Although the water may be collected from the rain pour, the water will be polluted by the chemical substance of mining activities. This affects the production of the paddy field.

The list of those impacts above have explained that the mining activities carried out by PT, Tripabara has disadvantaged the society of Lunang Utara Sub-district. The society residing around the mining location along with some youths who are concerned with the impacts of the mining activities have reported this issue to Penghulu Nan Salapan. Unfortunately, there was no response made towards the report for Penghulu Nan Salapan believed that the company has analyzed and considered the risk of the mining activities.

As for the Ministry of Energy and Mineral Resources, a company has the authority to undergo the mining activities if it has fulfilled the required documents in accordance to the constitution article number 4 of 2009 and the article number 43 of 2015 on the Ethics of Evaluation towards Issuing Mineral and Coal Mining Business Permission. The company is not allowed to operate before the clean and clear permission has been issued. For this reason, the company processed the Business Permission Holder who was issued on July 1st, 2013.

Based on the explanation above, it can be seen that the constitution, rules, and other types of regulation exist. Thus, they may strengthen the position of PT. Tripabara to obtain the legal permission from the Ministry of Energy and Mineral Resources. This condition explains why PT. Tripabara has never been blamed for the environmental damages, and the conflict occurs in the society due to the mining activities in Lunang Utara Sub-district. The Ministry of Energy and Mineral Resources considers that the company has fulfilled the clean and clear legal permission to operate its mining activities.

The provincial and central government handles the implementation of constitution article number 23 of 2014 on issuing the mining permission, meanwhile, the monitoring responsibility is in the authority of the ministerial government. On the other hand, the regency and province government have no authority to monitor the mining activities, resulting in the loose control over the mining activities itself.

\section{Conclusion}

According to the explanation on the previous chapters, it can be concluded that the clean and clear permission does not affect the resolution of the conflict between the mining company and the society of Lunang Utara seen from the social as well as physical environmental management. Several causes to why the conflict prolongs are there were unshared profits of mining activities by the company to Penghulu Nan Salapan (local authorities), the decision which was not made based on the all society's aspirations, and there was no problem solving towards the environmental damage caused by the mining activities. Those conditions took place due to irresponsibility on both parties (the company and the society) on the regulations they have made.

\section{References}

[1] Sunyoto Usman. 2015. Esai-Esai Sosiologi,Perubahan Sosial, Pustaka Pelajar: Yogyakarta.

[2] Perkumpulan Huma, Pusat Database dan Informasi Data Konflik, Http://huma.or, accessed on 23 December 2015.

[3] Pusat Database dan Informasi Data Konflik, Http://huma.or, accessed on December 23rd 2015.

[4] Data Konflik Konflik Sumber Daya Alam Perkumpulan Qbar, on 2015. 
[5] Mineral mining is the mining of minerals such as ore or rocks, out of geothermal, crude oil and gas, as well as ground water. (Constitution Number 4 of 2009 on Mineral and Coal Mining Article 1, Number 4).

[6] Regulations made by the Ministry of Energy and Mineral Resources, Tata Cara Evaluasi Penerbitan Izin usaha Pertambangan, No. 43 of 2015 on Article 1, Number 15.

[7] The Presentation of Ministry of Energy and Mineral Resources Paper, Strategi Pengawasan Pertambangan Dalam Implementasi UU 23 Tahun 2014 dan Permen ESDM Nomor 43 Tahun 2015, by Sri Raharjo, M, Eng, on 18 October 2016 in Padang, Page 13

[8] Ministry of Energy and Mineral Resources, Clear and Clean Menjadi Izin Usaha Pertambangan, www.djmbp.esdm.go.id, accessed on January 27th 2016

[9] Ministry of Energy and Mineral Resources Paper Presentation, Koordinasi dan Supervisi Atas Pengelolaan Pertambangan Mineral dan Batubara Di Provinsi Nangroeh Aceh Darussalam, Sumatera Utara, Sumatera Barat, Riau Bengkulu, Lampung, Sulawesi Barat, Gorantalo Sulawesi Utara, dan Papua di Bali, on December 4th 2014, Page.10-11 